\title{
Hibiscus sabdariffa extract as anti-aging supplement through its antioxidant and anti-obesity activities
}

\author{
Zuliana Muhamad Ridzwan Krishnamurthy*, Insathe Mohd Ali, Mohamad Dayoob, Shahad Shakho Hussein, \\ Nurzalina Abdul Karim Khan
}

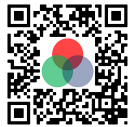

Use your smartphone to scan this QR code and download this article

Department of Pharmaceutical Technology, School of Pharmaceutical Sciences, Universiti Sains Malaysia

Correspondence

Zuliana Muhamad Ridzwan Krishnamurthy, Department of Pharmaceutical Technology, School of Pharmaceutical Sciences, Universiti Sains Malaysia

Email: zulianaridzwan@gmail.com

History

- Received: Sept 292019

- Accepted: Nov 202019

- Published: Jan 292020

DOI : 10.15419/bmrat.v7i1.584

\section{Check for updates}

\section{Copyright}

(c) Biomedpress. This is an openaccess article distributed under the terms of the Creative Commons Attribution 4.0 International license.

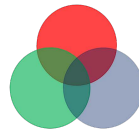

\begin{abstract}
Introduction: Imbalance between total energy intake and expenditure causes accumulation of excess fat and sugar in the body which leads to development of diabetes mellitus type II, obesity, and metabolic syndrome. These harmful diseases accelerate aging and cause fatal metabolic disorders as people age. Inhibition of pancreatic lipase, and alpha glucosidase digestive enzymes is a step that can reduce excess fat and sugar from the body, which is an essential component of healthy aging. Methodology: In this study, aqueous and 50\% ethanolic extracts of Hibiscus sabdariffa were investigated for their inhibitory activities on pancreatic lipase and alpha-glucosidase, in addition to their antioxidant activities (using UV-vis spectrophotometer). Results: Both extracts displayed antioxidant properties, indicated by $\mathrm{IC}_{50}$ of $516 \pm 6.80 \mu \mathrm{g} / \mathrm{mL}$ for $\mathrm{H}$. sabdariffa aqueous extract and $280 \pm 9.10 \mu \mathrm{g} / \mathrm{mL}$ for $\mathrm{H}$. sabdariffa $50 \%$ ethanolic extract. The extracts also suppressed the activities of pancreatic lipase and alpha-glucosidase enzymes, which suggests possible anti-obesity and anti-diabetic activities. $H$. sabdariffa aqueous extract inhibited pancreatic lipase activity with $\mathrm{IC}_{50}$ of

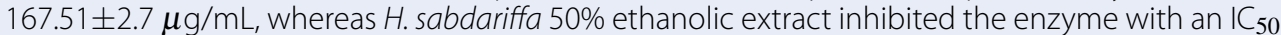
of $790.65 \pm 16.02 \mu \mathrm{g} / \mathrm{mL}$. Both H. sabdariffa aqueous and ethanolic extracts also successfully inhibited alpha-glucosidase enzyme activity with $\mathrm{IC}_{50} 949.88 \pm 10.83 \mu \mathrm{g} / \mathrm{mL}$, and $378.33 \pm 4.20 \mu \mathrm{g} / \mathrm{mL}$, respectively. Conclusion: Taken together, the outcome of the investigations offers the possibility of the extracts as an anti-obesity, anti-diabetic, anti-metabolic and anti-aging agent, which can be developed into supplements for adults to prevent the occurrence of these prevalent diseases and delay the onset and effects of aging.
\end{abstract}

Key words: Hibiscus sabdariffa, pancreatic lipase, alpha-glucosidase, antioxidant, anti-obesity

\section{INTRODUCTION}

Malaysia will be an aging country by 2020 where $7 \%$ of the country's population will be at the age of 65 or above $^{1}$, and in just 23 years after that, the Malaysian aged population will double to $14 \%^{2}$. Ensuring physical health and well-being of older adults is crucial, in part, to reduce incidences of ill health and hospitalization so that people can actively participate in society. Biologically, aging is a time-related functional decline of various organs and tissues that are involved in survival and fertility of an organism. It is mainly caused by oxidative damage ${ }^{3}$ and metabolic dysregulation ${ }^{4}$. Older adults are burdened with the development of fatal metabolic related diseases, such as cardiovascular disorders, high blood pressure, type II diabetes mellitus, insulin resistance, hyperlipidemia, hypercholesterolemia, and obesity. Metabolic syndrome is defined as a cluster of diseases which are associated with the development of cardiovascular disorders ${ }^{5}$, mainly caused by accumulation of excess fat and sugar in the body. The pervasiveness of metabolic syndromes rises with age ${ }^{6,7}$. Development of metabolic syndrome is $15 \%$ higher in patients above the age of 40 compared to the younger ones ${ }^{8}$. For every year of increase in age, the risk of metabolic syndrome increases by $3 \%{ }^{9}$. Obesity is the most significant marker for development of metabolic syndrome ${ }^{10}$. Obesity also accelerates aging, and incremental increases in the adipocyte level increases systemic ROS levels ${ }^{4}$. In short, accumulation of excess fat and sugar is one of the factors leading to aging symptoms and most metabolicrelated problems that arise as one ages.

Natural products are well-known for their synergistic action of bioactive compounds, thereby facilitating a more anti-oxidative and multi-targeted approach compared to currently available single drugs ${ }^{11}$. Hibiscus sabdariffa is a medicinal plant well-known for its therapeutic values, including anti-hyperglycemic, anti-hypercholesteremic, and thermogenesis-enhancement potential of its aqueous extract ${ }^{12}$. It is also rich in bioactive compounds, including delphinidin-3-glucoside, cyanidin-3-glucoside, delphinidin-3-sambubioside, 
and cyanidin-3-sambubioside ${ }^{13}$. Delphinidins possess numerous pharmacological activities, such as antioxidant, anti-inflammatory, anti-cancer, and anti-obesity properties ${ }^{14}$. Delphinidins inhibit adipogenesis and anti-obesity attributes ${ }^{15,16}$. Anthocyanidins have anti-cancer, anti-diabetic and anti-obesity properties ${ }^{17}$, and cyanidin-3-glucoside has also been reported to have good antioxidative capacity ${ }^{18}$.

Targeting a plant which has synergistic antioxidant, alpha-glucosidase enzyme and pancreatic lipase enzyme inhibitory effects can delay the onset of biological aging and minimize glucose and fat absorption for preventing development of metabolic-related diseases. Thus, plant-based therapy may be a reliable approach to improve the general health and well-being of older adults. Hence, the current research study aims to evaluate the total phenolic and flavonoid contents of $H$. sabdariffa calyx extracts, as well as its antioxidant, alpha-glucosidase and pancreatic lipase inhibitory properties, to determine the potential of $H$. sabdariffa as an anti-aging health supplement.

\section{MATERIALS AND METHODS}

\section{Extraction}

One liter of extracting solvent (distilled water for aqueous extract and 50\% ethanol for ethanolic extract) was added to $100 \mathrm{~g} \mathrm{H}$. sabdariffa calyx (purchased from Herbagus Sdn. Bhd., Pulau Pinang; collected from Kepala Batas, Pulau Pinang area in October 2016.), sonicated for 1 hour, and macerated under dark condition for $24 \mathrm{~h}$ at $20^{\circ} \mathrm{C} \pm 5$. The mixture was then filtered with muslin cloth to separate plant material from fluid extract. The fluid extract was re-filtered using a rotary vacuum filter to remove any remaining coarse material. For aqueous extract, the filtered fluid extract was spray dried using Mini Spray Dryer B-290 (BUCHI, New Castle) at inlet temperature of $80^{\circ} \mathrm{C}$, aspirator rate of $100 \%$ and flow rate of $5 \%$. For $50 \%$ ethanolic extract, the filtered fluid extract was diluted with distilled water to 20:80 ethanol to water ratio prior to spray drying.

\section{Determination of total phenolics}

Total phenolic content (TPC) of $H$. sabdariffa aqueous and 50\% ethanolic extract was determined using Folin-Ciocalteu (FC) reagent (Sigma Aldrich, St. Louis, MO) and gallic acid (Sigma Aldrich, St. Louis, $\mathrm{MO}$ ), per standard protocol with slight modifications. In a test tube, $400 \mu \mathrm{L}$ of $1 \mathrm{mg} / \mathrm{mL} \mathrm{H}$. sabdariffa extract was added to $2 \mathrm{~mL} \mathrm{FC} \mathrm{reagent.} \mathrm{After} \mathrm{incubating}$ in the dark at $20^{\circ} \mathrm{C} \pm 5$ for 5 minutes, $1.6 \mathrm{~mL}$ of $7.5 \%$ sodium carbonate (Sigma Aldrich) was added into the mixture. The final mixture was incubated in the dark at $20^{\circ} \mathrm{C} \pm 5$. The absorbance was measured at $765 \mathrm{~nm}$ using an UV-Vis spectrophotometer. A calibration curve of gallic acid standard was constructed. All results are expressed as mg gallic acid extract (GAE) per g extract.

\section{Determination of total flavonoids}

Total flavonoid contents were determined by the aluminum calorimetric method ${ }^{19}$. In a 96-well plate, $150 \mu \mathrm{L}$ of $1 \mathrm{mg} / \mathrm{mL} H$. sabdariffa extract was added to $150 \mu \mathrm{L}(2 \%)$ aluminum chloride $\left(\mathrm{AlCl}_{3}\right)$ (SigmaAldrich). After incubating for $15 \mathrm{~min}$ at $20^{\circ} \mathrm{C} \pm 5$, the absorbance was measured at $435 \mathrm{~nm}$ using a spectrophotometer. A calibration curve of quercetin (Sigma-Aldrich) standard was constructed. All results were expressed as mg quercetin extract (QE) per g extract.

\section{Antioxidant activity determination}

The 2,2-diphenyl-1-picrylhydrazyl (DPPH) (SigmaAldrich) free radical scavenging capacity of $H$. sabdariffa aqueous and $50 \%$ ethanolic extracts was evaluated according to Chin (2012) ${ }^{20}$. H. sabdariffa aqueous and $50 \%$ ethanolic extracts were serially diluted at a dilution factor of 2 - from $2000 \mu \mathrm{g} / \mathrm{mL}$ to 125 $\mu \mathrm{g} / \mathrm{mL}$. Ascorbic acid was also serially diluted from $125 \mu \mathrm{g} / \mathrm{mL}$ to $1.95 \mu \mathrm{g} / \mathrm{mL}$, at a dilution factor of 2 . Fifty $\mu \mathrm{L}$ of extract (or standard) was then added to $950 \mu \mathrm{L}$ of $200 \mu \mathrm{M}$ ethanolic DPPH solution, vortexed, and incubated at $37^{\circ} \mathrm{C}$ for $30 \mathrm{~min}$. The absorbance of the mixtures at various concentrations was measured at $517 \mathrm{~nm}$ using an UV-Vis spectrophotometer. The $\mathrm{IC}_{50}$ was analyzed using OriginPro software version 8.1 (Northampton, Massachusetts).

\section{In vitro pancreatic lipase inhibitory assay}

Firstly, $50 \mu \mathrm{L}$ of extract or orlistat standard (Cayman Chemical Company, Michigan, USA) was added to $100 \mu \mathrm{L}$ of $0.1 \mathrm{mg} / \mathrm{mL}$ porcine pancreatic lipase (Sigma Aldrich) in $\mathrm{pH} 6.8$ potassium phosphate buffer solution. The mixture was incubated at $37^{\circ} \mathrm{C}$ for $30 \mathrm{~min}$. Then, $50 \mu \mathrm{L}$ of $2.275 \mathrm{mM} p$-NPB (Sigma-Aldrich) in dimethyl formamide was added to the mixture and incubated at $37^{\circ} \mathrm{C}$ for $30 \mathrm{~min}$. The final concentration of extracts in the reaction media was $2500 \mu \mathrm{g} / \mathrm{mL}, 1250$ $\mu \mathrm{g} / \mathrm{mL}, 625 \mu \mathrm{g} / \mathrm{mL}, 312.5 \mu \mathrm{g} / \mathrm{mL}, 156.25 \mu \mathrm{g} / \mathrm{mL}, 78$ $\mu \mathrm{g} / \mathrm{mL}$, and $39.06 \mu \mathrm{g} / \mathrm{mL}$. The enzyme inhibitory activity of the plant extracts was calculated using the following equation, where $\mathrm{A}$ is the absorbance. The $\mathrm{IC}_{50}$ was analyzed using OriginPro software version 8.1 (Northampton, Massachusetts) ${ }^{21}$. 
In vitro alpha-glucosidase enzyme inhibitory assay

The potency of the plant extracts in alpha-glucosidase enzyme inhibitory activity was evaluated by measuring the hydrolysis of $p$-NPG to $p$-nitrophenol ion and glucose with minor modifications. Briefly, 5000 to $78.13 \mu \mathrm{g} / \mathrm{mL}$ acarbose standard solution was prepared by serial dilution with dilution factor of 2 . Then, $10 \mathrm{mg} / \mathrm{mL}$ of extract was prepared and serially diluted from $10,000 \mu \mathrm{g} / \mathrm{mL}$ to $156 \mu \mathrm{g} / \mathrm{mL}$, at a dilution factor of 2 , to prepare the working solutions. In a 96-well microplate, $50 \mu \mathrm{L}$ of sample or acarbose positive control (Bayer, Petaling Jaya, Malaysia) was added to $100 \mu \mathrm{L}$ of $1 \mathrm{U} / \mathrm{mL}$ alpha-glucosidase from Saccharomyces cerevisiae (Sigma-Aldrich) solution in potassium phosphate buffer $\mathrm{pH} 6.8$, and incubated for $10 \mathrm{~min}$ at $25^{\circ} \mathrm{C}$. Then, $50 \mu \mathrm{L}$ of $5 \mathrm{mM}$-NPG (Sigma-Aldrich) was added to each well and incubated at $25^{\circ} \mathrm{C}$ for $5 \mathrm{~min}$ before reading the absorbance at $405 \mathrm{~nm}$ on an UV-vis spectrophotometer. The final concentration of extracts in the reaction media was $2500 \mu \mathrm{g} / \mathrm{mL}, 1250 \mu \mathrm{g} / \mathrm{mL}, 625 \mu \mathrm{g} / \mathrm{mL}, 312.5 \mu \mathrm{g} / \mathrm{mL}$, $156.25 \mu \mathrm{g} / \mathrm{mL}, 78 \mu \mathrm{g} / \mathrm{mL}$, and $39.06 \mu \mathrm{g} / \mathrm{mL}$. The enzyme inhibitory activity of the plant extracts was calculated using the following equation, where $\mathrm{A}$ is the absorbance. $\mathrm{IC}_{50}$ was analyzed using OriginPro software (OriginLab, Northampton, MA, USA) ${ }^{22}$.

\section{Statistical analyses}

All analyses were performed in triplicate and data was reported as mean \pm SEM. One-way ANOVA was performed to assess the significant differences at $\mathrm{p}<0.05$. All analyses were carried out using Microsoft Excel 2010 (Microsoft Corporation, Redmond, WA, USA). The $\mathrm{IC}_{50}$ was analyzed using Origin Pro software.

\section{RESULTS}

\section{Determination of total phenolics and total flavonoids}

The total phenolic and flavonoid content in the extracts were determined by comparing them with gallic acid and quercetin standards, respectively. The total phenolics and flavonoids in the two extracts are reported in Table 1 as $\mathrm{mg}$ gallic acid/g extract and mg Quercetin/g extract, respectively. The phenolic and flavonoid content in $H$. sabdariffa 50\% ethanolic extract was significantly higher than in $H$. sabdariffa aqueous extract. Indeed, $H$. sabdariffa $50 \%$ ethanolic extract contained total phenolics of $15.56 \pm 0.02 \mathrm{mg}$ $\mathrm{GAE} / \mathrm{g}$ and total flavonoids of $3.53 \pm 0.00 \mathrm{mg} \mathrm{QE} / \mathrm{g}$, whereas H. sabdariffa aqueous extract contained total phenolics and flavonoids of $6.65 \pm 0.00 \mathrm{mg} \mathrm{GAE} / \mathrm{g}$ and $10.08 \pm 0.01 \mathrm{mg} \mathrm{QE} / \mathrm{g}$, respectively.

\section{Antioxidant activity determination}

The $\mathrm{IC}_{50}$ of $H$. sabdariffa aqueous and ethanolic extracts were determined through DPPH method, as reported in Table 2. H. sabdariffa 50\% ethanolic extract exhibited lower $\mathrm{IC}_{50}(280 \pm 9.1 \mu \mathrm{g} / \mathrm{mL})$, compared to aqueous extract which exhibited an $\mathrm{IC}_{50}$ of $516 \pm 6.8$ $\mu \mathrm{g} / \mathrm{mL}$.

\section{In vitro pancreatic lipase enzyme inhibitory assay}

Table 3 shows the pancreatic lipase enzyme inhibitory activities of $H$. sabdariffa extracts. The assay was performed using orlistat as a positive control which showed an $\mathrm{IC}_{50}$ of $6.39 \pm 0.14 \mu \mathrm{g} / \mathrm{mL}$. H. sabdariffa aqueous extract inhibited pancreatic lipase enzyme from $6.36 \pm 0.75 \%$ to $90.48 \pm 0.34 \%$ (with $\mathrm{IC}_{50} 167.51 \pm 2.7 \mu \mathrm{g} / \mathrm{mL}$ ), compared to $H$. sabdariffa $50 \%$ ethanolic extract which inhibited from $12.95 \pm 1.34 \mu \mathrm{g} / \mathrm{mL}$ to $79.76 \pm 0.49 \mu \mathrm{g} / \mathrm{mL}$ (with IC $_{50}$ $790.65 \pm 16.02 \mu \mathrm{g} / \mathrm{mL})$.

\section{In vitro alpha glucosidase enzyme in- hibitory assay}

The inhibitory activities of $H$. sabdariffa extracts against alpha-glucosidase enzyme is reported in Table 4. Acarbose was used as a positive control and showed $\mathrm{IC}_{50}$ of $75.71 \pm 0.96 \mu \mathrm{g} / \mathrm{mL}$. $H$. sabdariffa aqueous extract inhibited alpha glucosidase enzyme from $2.43 \pm 0.4 \%$ to $74.99 \pm 0.29 \%$ (with $\mathrm{IC}_{50} 949.88 \pm 10.83$ ), compared to $H$. sabdariffa $50 \%$ ethanolic extract which inhibited from $5.34 \pm 0.33$ to $86.11 \pm 0.15$ (with $\mathrm{IC}_{50} 378.33 \pm 4.2 \mu \mathrm{g} / \mathrm{mL}$ ).

\section{DISCUSSION}

Imbalance between total energy intake and expenditure causes accumulation of excess fat and sugar in the body which leads to obesity, type II diabetes mellitus, metabolic syndrome, and accelerated aging. The prevalence of obesity, diabetes mellitus type II, and metabolic syndromes also increases as one ages. Hence, inhibiting the activity of alpha glucosidase and pancreatic lipase enzyme activity may be a promising approach in overcoming problems related to accumulation of excess fat and sugar as one ages. Simultaneously, high content of antioxidants also slows 
Table 1: Total phenolics and flavonoid contents of $\boldsymbol{H}$. sabdariffa aqueousand $\boldsymbol{H}$. sabdariffa $50 \%$ ethanolic extracts

\begin{tabular}{lcc}
\hline Extracts & $\begin{array}{c}\text { Total phenolics } \\
(\mathrm{mg})\end{array}$ & $\begin{array}{c}\text { Total flavonoids } \\
(\mathrm{mg})\end{array}$ \\
\hline H. sabdariffa aqueous extrac & $6.65 \pm 0.000$ & $3.53 \pm 0.002$ \\
H. sabdariffa $50 \%$ ethanolic extract & $15.56 \pm 0.023$ & $10.08 \pm 0.012$ \\
\hline Result is reported in mean $+\operatorname{SEM}(\mathrm{n}=3)$ &
\end{tabular}

Table 2: DPPH free radical scavenging capacities of $\boldsymbol{H}$. sabdariffa aqueous and $H$. sabdariffa $50 \%$ ethanolic extracts compared to ascorbic acid standard

\begin{tabular}{lc}
\hline Extract & $\mathrm{IC}_{50} \pm \mathrm{SEM}(\mu \mathrm{g} / \mathrm{mL})$ \\
\hline Ascorbic acid & $42.74 \pm 2.6$ \\
H. sabdariffa aqueous extract & $516 \pm 6.80$ \\
H. sabdariffa 50\% ethanolic extract & $280 \pm 9.10$ \\
\hline
\end{tabular}

Result is reported as $\mathrm{IC}_{50} \pm \mathrm{SEM}(\mathrm{n}=3)$

Table 3: Pancreatic lipase enzyme inhibitory potency of H. sabdariffa aqueous and $H$. sabdariffa $50 \%$ ethanolic extracts compared to orlistat standard

\begin{tabular}{lc}
\hline Extract & IC50 \pm SEM $(\mu \mathrm{g} / \mathrm{mL})$ \\
\hline Orlistat & $6.39 \pm 0.14$ \\
H. sabdariffa aqueous extract & $167.51 \pm 2.7$ \\
H. sabdariffa $50 \%$ ethanolic extract & $790.65 \pm 16.02$ \\
\hline Result is expressed as IC $_{50} \pm$ SEM $(\mathrm{n}=3)$ &
\end{tabular}

Table 4: Alpha-glucosidase enzyme inhibitory potency of $\boldsymbol{H}$. sabdariffa aqueous and $\boldsymbol{H}$. sabdariffa $\mathbf{5 0} \%$ ethanolic extracts compared to acarbose standard

\begin{tabular}{lc}
\hline Extract & $\mathrm{IC}_{50} \pm \mathrm{SEM}(\mu \mathrm{g} / \mathrm{mL})$ \\
\hline Acarbose & $75.71 \pm 0.96$ \\
H. sabdariffa aqueous extract & $949.88 \pm 10.83$ \\
H. sabdariffa $50 \%$ ethanolic extract & $378.33 \pm 4.20$ \\
\hline
\end{tabular}

Result is expressed as $\mathrm{IC}_{50} \pm \operatorname{SEM}(\mathrm{n}=3)$

down the aging process. Thus, the current study investigated the antioxidant, anti-pancreatic lipase and anti-alpha glucosidase activities of Hibiscus sabdariffa aqueous and $50 \%$ ethanolic extract.

The extract is targeted to be delivered in the intestines to inhibit the dietary enzymes and to be absorbed into the circulatory system to act as antioxidants. Thus, it is most suitable to be delivered as an oral dose form. Water and ethanol are two solvents which are least toxic compared to others for the development of oral dose form. Extraction with water and 50\% ethanol showed high yield compared to $100 \%$ ethanolic extract. Thus, $H$. sabdariffa calyx was extracted with water and $50 \%$ ethanol, respectively, to study their an- tioxidant, anti-pancreatic lipase, and anti-alpha glucosidase potency.

ROS are generated from biochemical reactions and dietary xenobiotics. They initiate chain reaction and cause oxidative stress which cause damage to cells and organs. Antioxidants inhibit oxidation, terminate chain reaction, prevent cell damage, thereby delaying aging. Plants are rich with bioactive compounds, mainly phenolics, which are well-known for antioxidant properties. The antioxidant activities of H. sabdariffa extracts was determined using TPC, TFC, and DPPH assays. Both extracts were found to contain significant amount of phenolics and flavonoids, and to exhibit antioxidant activity against DPPH. However, 


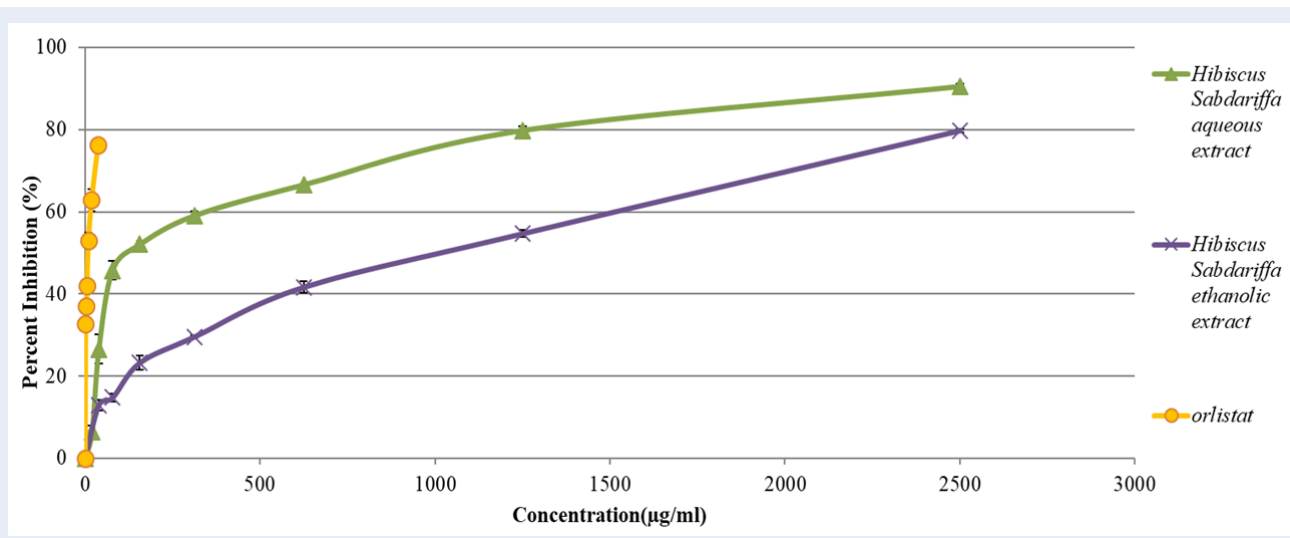

Figure 1: Porcine pancreatic lipase enzyme inhibitory activity of $\boldsymbol{H}$. sabdariffa aqueous and $\boldsymbol{H}$. sabdariffa $50 \%$ ethanolic extracts compared to orlistat standard. Result is expressed as $I C_{50} \pm S E M(n=3)$.

H. sabdariffa $50 \%$ ethanolic extract contain higher phenolics and flavonoids compared to the aqueous extract. Corresponding to the phenolic and flavonoid contents, the antioxidant activity was also observed to be higher in $50 \%$ ethanolic extract $(280 \pm 9.10$ $\mu \mathrm{g} / \mathrm{mL})$.

Accumulation of fat increases adipose tissue mass and ROS levels, which initiate a chain reaction leading to damage of organs and acceleration of aging. Moreover, the prevalence of metabolic disorders due to accumulation of excess fat and sugar among older people are high. Thus, inhibiting the activity of alpha glucosidase and pancreatic lipase dietary enzymes may reduce absorption of fat and glucose in the body, and prevent accumulation of fat and generation of ROS. In addition, metabolic disorders due to accumulation of excess fat and sugar among older people can be solved. Alpha-glucosidase enzyme breaks down large polysaccharides into simpler monosaccharides or disaccharides. Similarly, pancreatic lipases break down large triglycerides into simpler glycerol and fatty acid. High activities of these enzymes enhance the absorption of sugar and fat into the systemic circulatory system. Therefore, inhibiting the activities of these enzymes is a key target to minimize fat and sugar absorption, and is a widely studied mechanism to investigate the potency of natural products, such as anti-obesity agents $^{23}$. Orlistat, a potent pancreatic lipase inhibitor has been shown to prevent $30 \%$ of dietary fat absorption from the intestines into the bloodstream ${ }^{24}$. However, it is also associated with side effects including abdominal cramping, fat-soluble vitamin deficiencies, liquid stools, and fecal urgency ${ }^{25}$. Current research indicates that both $H$. sabdariffa aqueous and ethanolic extracts have high antioxidant activity and successfully inhibit pancreatic lipase and alpha-glucosidase enzyme activities. However, $H$. sabdariffa aqueous extract showed higher potency in inhibiting pancreatic lipase enzyme with an $\mathrm{IC}_{50}$ of $167.51 \pm 2.7 \mu \mathrm{g} / \mathrm{mL}$ (Figure 1). It inhibits the enzyme from $6.36 \%$ to $90.48 \%$. On the other hand, H. sabdariffa $50 \%$ ethanolic extract inhibited alpha-glucosidase with $\mathrm{IC}_{50}$ of $378.33 \pm 4.20 \mu \mathrm{g} / \mathrm{mL}$ (Figure 2). Thus, both extracts show good candidacy to be developed into antioxidant supplements to eliminate excess fat and sugar from the body and to slow down the process of aging.

The phytochemicals in plant extracts, including phenolic compounds, flavonoids, anthocyanidins and other compounds, have potent alpha glucosidase and pancreatic lipase enzyme inhibitory potential ${ }^{26}$ - For instance, ethyl acetate extract of Vitis rotundifolia exhibited potent alpha-glucosidase and pancreatic lipase inhibitory activity ${ }^{27}$. Similarly, alpha-glucosidase and pancreatic lipase enzyme inhibitory activity of Nelumbo nucifera leaves was also reported $^{28}$. Natural antioxidants including polyphenols, ascorbic acid and tocopherols have also been reported to have pancreatic lipase inhibitory effect ${ }^{29}$. Some flavanols have also been reported to be potent inhibitors of pancreatic lipase activity ${ }^{30,31}$. Belfeki et al. (2016) also reported a strong positive correlation between antioxidant capacity and digestive enzyme inhibitory activities of several plants ${ }^{32}$.

\section{CONCLUSION}

Most complications, including metabolic syndromes that develop as one ages, are caused by accumulation of excess sugar and fat in the body. Accumulation of fat in adipocytes elevates oxidative damage and accelerates aging. Current research revealed 


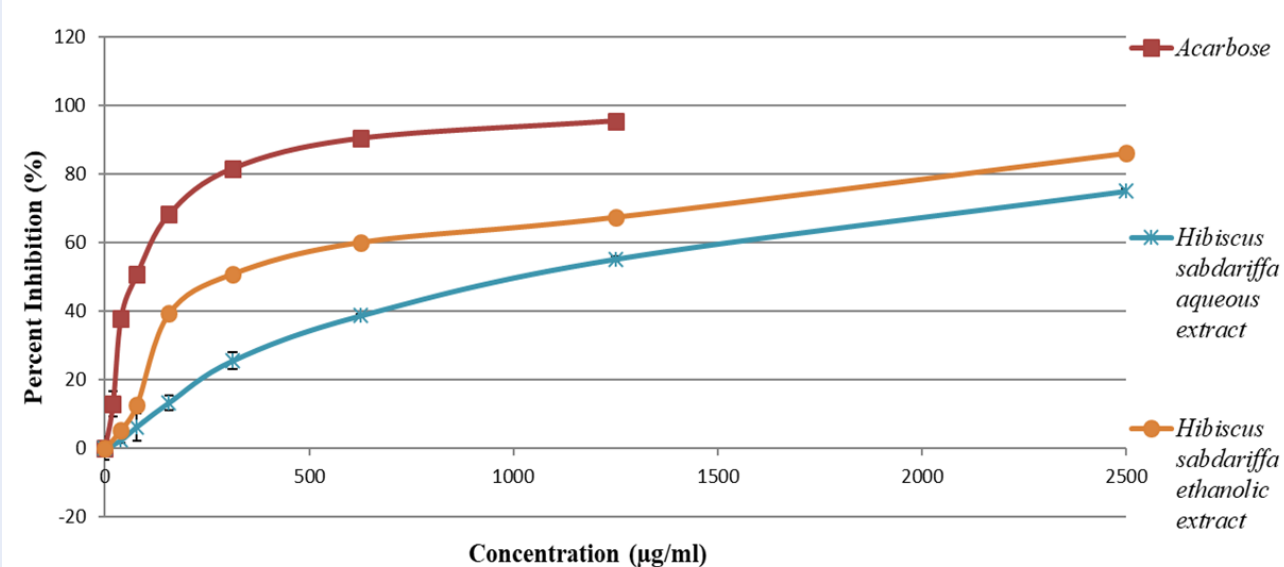

Figure 2: Alpha-glucosidase enzyme inhibitory activity of $\boldsymbol{H}$. sabdariffa aqueous and $\boldsymbol{H}$. sabdariffa $\mathbf{5 0} \%$ ethanolic extracts compared to acarbose standard. Result is expressed as $I_{50} \pm S E M(n=3)$

that $H$. sabdariffa aqueous and ethanolic extracts contain high phenolic content and have good therapeutic values, including antioxidative, anti-pancreatic lipase and anti-alpha-glucosidase activities. Hence, it can be a good alternative for elimination of excess fat and sugar from the body and can be a potential candidate to develop as supplements or functional food that could contribute to anti-aging, anti-obesity, anti-diabetic and anti-metabolic syndrome for older adults. However, this is a preliminary in vitro study and requires further investigations, including in vivo assays and human trials.

\section{ABBREVIATIONS}

DMF: Dimethyl formamide

DPPH: 2,2-diphenyl-1-picrylhydrazyl

FC: Follin- Ciocalteau's

GAE: Gallic acid equivalent

IC $_{50}: 50 \%$ inhibitory concentration

p- NPB: $p$-Nitrophenyl butyrate

p- NPG: $p$-Nitrophenyl glucopyranoside

QE: Quercetin equivalent

ROS: Reactive oxygen species

TFC: Total flavonoid content

TPC: Total phenolic content

\section{COMPETING INTERESTS}

The authors declare no conflict of interest.

\section{AUTHORS' CONTRIBUTIONS}

Zuliana Ridzwan designed the experiment, conducted primary literature search, carried out pancreatic lipase and alpha-glucosidase inhibitory assay and drafted the manuscript. Nurzalina Abdul Karim Khan was the project leader who supervised the research and managed the grant sponsorship. Insathe Mohd Ali carried out total phenolics and total flavonoids determining assays. Mohd Dayoob carried out the extraction of Hibiscus sabdariffa calyx. Shahad Hussein conducted antioxidant assay.

\section{ACKNOWLEDGMENTS}

This research was supported by a grant from the National Institutes of Biotechnology Malaysia, PFARMASI/304/K105/650904.

\section{REFERENCES}

1. Tyng CS, Hamid TA. Population ageing and the Malaysian chinese: issues and challenges. Malaysian J Chinese Stud. 2015;4(1):1-13.

2. Baharin R, Saad S. Ageing population and health care expenditure: evidence using time series analysis. Malaysian J Soc Sp. 2018;14(4):65-73. Available from: 10.17576/geo-2018-140406.

3. Finkel $\mathrm{T}$, Holbrook NJ. Oxidative Stress, aging. Nature. 2000;408(Nov):239-47. PMID: 11089981. Available from: $10.1038 / 35041687$

4. Ahima RS. Connecting obesity, aging and diabetes. Nat Med. 2009;15(9):996-7. PMID: 19734871. Available from: 10.1038/ nm0909-996.

5. Eckel RH, Grundy SM, Zimmet PZ. The metabolic syndrome. Lancet. 2005;365(9468):1415-28. PMID: 15836891. Available from: 10.1016/S0140-6736(05)66378-7.

6. Mohamud WN, Ismail A, Khir AS, Ismail IS, Musa KI, Kadir KA, et al. Prevalence of metabolic syndrome and its risk factors in adult Malaysians: results of a nationwide survey. Diabetes Res Clin Pract. 2012;96(1):91-7. PMID: 22553777. Available from: 10.1016/j.diabres.2011.11.020.

7. Tan WS, Ng CJ, Khoo EM, Low WY, Tan HM. The triad of erectile dysfunction, testosterone deficiency syndrome and metabolic syndrome: findings from a multi-ethnic Asian men study (The Subang Men's Health Study). Aging Male. 2011;14(4):231-6. PMID: 22115177. Available from: 10.3109/ 13685538.2011 .597463$. 
8. Lim KG, Cheah WK. A review of metabolic syndrome research in Malaysia. Med J Malaysia. 2016;71(June):20-8. PMID: 27801385.

9. Chee HP, Hazizi AS, Nisak MYB, Nasir MTM. Metabolic risk factors among government employees in Putrajaya, Malaysia. Sains Malays. 2014;43(8):1165-74.

10. Després JP, Lemieux I. Abdominal obesity and metabolic syndrome. Nature. 2006;444(7121):881-7. PMID: 17167477. Available from: 10.1038/nature05488.

11. Brusotti G, Cesari I, Dentamaro A, Caccialanza G, Massolini G. Isolation and characterization of bioactive compounds from plant resources: the role of analysis in the ethnopharmacological approach. J Pharm Biomed Anal. 2014;87:218-28. PMID: 23591140. Available from: 10.1016/j.jpba.2013.03.007.

12. Mohamed GA, Ibrahim SR, Elkhayat ES, El DR. Natural antiobesity agents. Bull Fac Pharm Cairo Univ. 2014;52(2):269-84. Available from: 10.1016/j.bfopcu.2014.05.001.

13. Jabeur I, Pereira E, Barros L, Calhelha RC, Soković M, Oliveira $M B$, et al. Hibiscus sabdariffa $L$. as a source of nutrients, bioactive compounds and colouring agents. Food Res Int. 2017;100(Pt 1):717-23. PMID: 28873741. Available from: 10.1016/j.foodres.2017.07.073.

14. Patel K, Jain A, Patel DK. Medicinal significance, pharmacological activities, and analytical aspects of anthocyanidins 'delphinidin': A concise report. J Acute Dis. 2013;2(3):169-78. Available from: 10.1016/S2221-6189(13)60123-7.

15. Harada G, Onoue S, Inoue C, Hanada S, Katakura $Y$. Delphinidin-3-glucoside suppresses lipid accumulation in HepG2 cells. Cytotechnology. 2018;70(6):1707-12. PMID: 30155609. Available from: 10.1007/s10616-018-0246-0.

16. Rahman N, Jeon M, Kim YS. Delphinidin, a major anthocyanin, inhibits 3T3-L1 pre-adipocyte differentiation through activation of Wnt/ $\beta$-catenin signaling. Biofactors. 2016;42(1):49-59. PMID: 26816335

17. Lee YM, Yoon $Y$, Yoon H, Park HM, Song S, Yeum KJ. Dietary anthocyanins against obesity and inflammation. Nutrients. 2017;9(10):1-15. PMID: 28974032. Available from: $10.3390 /$ nu9101089.

18. Tsuda T. Recent progress in anti-obesity and anti-diabetes effect of berries. Antioxidants. 2016;5(2):13.

19. Quettier-Deleu C, Gressier B, Vasseur J, Dine T, Brunet C, Luyckx $\mathrm{M}$, et al. Phenolic compounds and antioxidant activities of buckwheat (Fagopyrum esculentum Moench) hulls and flour. J Ethnopharmacol. 2000;72(1-2):35-42. PMID: 10967451. Available from: 10.1016/S0378-8741(00)00196-3.

20. Chin LS. Investigation of skin anti-ageing effects of three Chromolaena odorata ethanol extracts. Universiti Sains malaysia; 2012. .

21. Supkamonseni $N$, Thinkratok A, Meksuriyen D, Srisawat R. Hypolipidemic and hypoglycemic effects of Centella asiatica ( $\mathrm{L}$
.) extract in vitro and in vivo. 2014:52(Oct):965-971.

22. Johnson MH, de Mejia EG, Fan J, Lila MA, Yousef GG. Anthocyanins and proanthocyanidins from blueberry-blackberry fermented beverages inhibit markers of inflammation in macrophages and carbohydrate-utilizing enzymes in vitro. Mol Nutr Food Res. 2013;57(7):1182-97. PMID: 23526625. Available from: 10.1002/mnfr.201200678.

23. Marrelli $M$, Loizzo MR, Nicoletti M, Menichini F, Conforti $F$. In vitro investigation of the potential health benefits of wild Mediterranean dietary plants as anti-obesity agents with $\alpha$ amylase and pancreatic lipase inhibitory activities. J Sci Food Agric. 2014;94(11):2217-24. PMID: 24535986. Available from: 10.1002/jsfa.6544.

24. Ado MA, Abas F, Mohammed AS, Ghazali HM. Anti- and pro-lipase activity of selected medicinal, herbal and aquatic plants, and structure elucidation of an anti-lipase compound. Molecules. 2013;18(12):14651-69. PMID: 24287996. Available from: 10.3390/molecules181214651.

25. Lunagariya NA, Patel NK, Jagtap SC, Bhutani KK. Inhibitors of pancreatic lipase: state of the art and clinical perspectives. EX CLI J. 2014;(13):897-921.

26. Rahim AT, Takahashi Y, Yamaki K. Mode of pancreatic lipase inhibition activity in vitro by some flavonoids and non-flavonoid polyphenols. Food Res Int. 2015;75:289-94. PMID: 28454959. Available from: 10.1016/j.foodres.2015.05.017.

27. You $Q$, Chen $F$, Wang $X$, Jiang $Y$, Lin S. Anti-diabetic activities of phenolic compounds in muscadine against alphaglucosidase and pancreatic lipase. Lebensm Wiss Technol. 2012;46(1):164-8. Available from: 10.1016/j.lwt.2011.10.011.

28. Liu S, Li D, Huang B, Chen Y, Lu X, Wang Y. Inhibition of pancreatic lipase, $\alpha$-glucosidase, $\alpha$-amylase, and hypolipidemic effects of the total flavonoids from Nelumbo nucifera leaves. J Ethnopharmacol. 2013;149(1):263-9. PMID: 23811214. Available from: 10.1016/j.jep.2013.06.034.

29. Sahib NG, Hamid AA, Saari N, Abas F, Dek MSP, Rahim M. Antipancreatic lipase and antioxidant activity of selected tropical herbs. Int J Food Prop. 2012;15(3):569-78. Available from: 10. 1080/10942912.2010.494754.

30. Dechakhamphu A, Wongchum N. Screening for antipancreatic lipase properties of 28 traditional Thai medicina herbs. Asian Pac J Trop Biomed. 2015;5(12):1042-5. Available from: 10.1016/j.apjtb.2015.09.012.

31. Sergent T, Vanderstraeten J, Winand J, Beguin P, Schneider YJ. Phenolic compounds and plant extracts as potential natural anti-obesity substances. Food Chem. 2012;135(1):68-73. Available from: 10.1016/j.foodchem.2012.04.074.

32. Belfeki $H$, Mejri M, Hassouna M. Antioxidant and anti-lipases activities in vitro of Mentha viridis and Eucalyptus globulus extracts. Ind Crops Prod. 2016;89:514-21. Available from: 10.1016/j.indcrop.2016.06.002. 